DEMONSTRATION OF CIRCULATING IMMUNE COMPLEXES (CICS)

217 CONTAINING HUMAN THYROGLOBULIN (HUTg) IN A PATIENT WITH IMMUNE COMPLEX GLOMERULONEPHRITIS (ICGN) MEDIATED BY THYROGLOBULIN ANTI-THYROGLOBULIN IMMUNE COMPLEXES. Jordan, S.C., Buckingham, B.A., Olson, D.L., Perelman, A.J., Kogut, M.D., and Fine, R.N., Univ.So.Calif.Sch.Med, and Childrens Hospital of Los Angeles, California

A pediatric patient ( $p t)$ with Graves disease and circulating anti-Tg antibody (ab) levels developed ICGN characterized by mesangial, subendothelial and subepithelial dense deposits by electron microscopy. Renal cortex $t$ issue examined by direct immunofluorescence (IF) demonstrated granular glomerular immunoglobulin ( $\mathrm{g}$ ) and complement (C') deposition. Indirect if demonstrated granular glomerular and mesangial deposits of HuTg. Indirect IF also showed that eluates of the pt's kidney contained (ab) reactive with thyroid follicular cells and colloid. CICs were demonstrated in the pt's sera by both the Rajl cell assay and Clq solld phase assay. The indirect IF Raji assay demonstrated HuTg in ICs bound to the Raji cells. That HuTg was the antigenic component of CICs was further documented by a marked decrease Raji cell binding of CICs in the pt's sera when the sera was preincubated with HuTg. ICs eluted from both renal cortex tissue and CICs bound to Raji cells were analyzed by immunoelectrophoresis techniques and found to contain HuTg. We concluded that HuTganti-HuTg CICs have nephritogenic capacity and are important in induction and perpetuation of ICGN.

\section{ANTITHYROID ANTIBODY IN ALPORT SYNDROME}

Shigehiro Fujimoto, Shinzabro Hattori, Toshiko Namikawa, Akio Fruse, Ichiro Matsuda, Dept. Pediat. Kumamoto Univ. Med. JPN.

4 of 6 patients with Alport syndrome from 3 different families showed prescence of antithyroid antibody(ATA), and absence of anti DNA and anti nuclear antibody. 4 healthy members of these families, 22 patients with familiar nephritis without deafness from 7 families and 10 patients with sporadic hematuria showed negative ATA. In general adult population 16 of 1000 subjects have positive titer of ATA. When often reported data are taken into account together with this survey, 14 of 19 patients with Alport syndrome have positive titer of ATA, indicating significant higher incidence of ATA in the disease.
220

A IIOLOGICAL ACTIVITY OF IIMUNE COMPLAXIS DEPOSITEDD IN GLONILRULI OF VARIOUS RENAL DISUASUS IN Cil ILDHOOD. Thliada. T, Yandethar. T, Yumainoto. T,Noriti. T, Kiharä. I., Delt. of Pediat., YoInst. Iiephrol. Miluata Univ. Sch. lied., Mileata Jayan.

In order to deterine the biolotical activity of IC in slomeruli, we studied about 40 renal patients $"$ ith the method Yamamoto described. 40 cises diagnosed by renal biopsy ":ere IgA nehropathy (3), LW(5), Henocil-šchoenle in nephropatily (9) MPGN(7), lis(2), AGN(5), and lipoid neihrosis $(4)$. Among 40 patients kidney biopsies ere obtained at intervals from $2 I$ cases. A biolosical act1vity of IC as cemonstrated :ith the number of polymorphnuclear leukocytes(PNiN) attached in patient's clomeruli. In patients ith lipold noiprosis, ottachment of PMN als not scen. In MPGN, purpura nephritic and $L N$, the number increased significantly. Though, among the inmunofluorecent findings of kidney b1opsies obtained at intervals from 2I cases, I8 cases ":ere almwst sinilar, the number of PMN attached in glomeruli decreased in the cases ith the clinfcal improvement. These results indicete that this method is useful to observe the degree of histolocical and cinical activity of clomerulonephritis in re-biopsies.

\begin{abstract}
221 CIRCULATING IMMUNE COMPLEXES(CIC) IN ACUTE POSTSTREPTOCOCCAI GLOMERULONEPHRITIS(APSG
AND STEROII) SENSITIVE NEPHROTIC SYNDROME

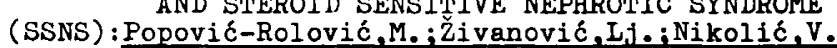
Miloševic-Jovčic, N. , Children's University Hospital' and Institute for Medical Research, Beograd, Yugoslavia The purpose of this study is to report the findings of CIC using Polyethylene glycol precipitation technique(PEG)and modified variant of inhibition of RF Latex agglutination test(RF-inh.) in 18 patients with APSGN, in 18 postnephritic children who recovered from the acute phase of APSGN 2-4 years earlier and 18 patients with SSNS.

CIC were found in $14 / 18$ patients with APSGN when tested during the first three weeks of the disease using PEG and in $11 / 13$ using RF-inh. Sequential determination of CIC showed the highest values of CIC within 3-5 weeks of the disease. In acute phase grosa hematuria was found in $13 / 14$ patients with CIC and only in $1 / 4$ without CIC; there was no difference in severity of proteinuria and serum creatinine.In 18 postnephritic children CIC were not found. In patients with SSNS, CIC were found in 12/14 while relapsing. During the follow-up these 12 patients had 26 relapses and CIC were found in $17 / 26$ and $10 / 21$ using $\mathrm{PEG}$ and $\mathrm{RF}$-inh. respectively.In remission CIC were found only occasionally.
\end{abstract}

IMMUNOLOGIC STUDIES IN SHUNT NEPHRITIS CAU-

219 SED BY MICROCOCCUS AND STAPH. ALBUS INFECTION. Leumann E.P., Briner J., Joller P.., Odermatt B., Seger R. Dept. of Pediatrics and Pathology, University of zurich, Switzerland.

Two pediatric patients with shunt nephritis, one infected by Micrococcus (M), and the other by Staph. albus (S), were studied. Both exhibited cryoglobulinemia, elevated IgG indicating chronic infection, and very high agglutinating antibody titers $(1: 4000)$ against the respective organisins ( $M$ and $S$ ) cultured from the patients' blood. After revision of the shunts, the half life of the specific antibodies was determined.

Renal biopsies disclosed membranoproliferative glomerulonephritis type I (M) and type III (S). Granular deposits containing Clq, C3, IgM and IgG were detected at immunofluorescence examination. The glomerular immune deposits are currently being investigated for the presence of micrococcal and staphylococcal antigens.
DETECTION OF CIRCULATING IMMUNE COMPLEXES IN PATIENTS

222 WITH GLOMERULONEPHRITIS

Yamada, Y., Katayama, K., Uehara, S., Ikeuchi, H., Matsuo, T., Dept. of Pediatrics, Kobe University School of Medicine, Kobe-shi, Hyogo-ken, Japan

Circulating immune complexes(CIC) are involved in the pathogenesis of various renal diseases. In eighty children with renal disease, CIC were measured using the Raji cell immunofluorecent method(Theofilopoulos's method). This method gave us high positive results in pationts with acute glomerulonephritis(ACN) and chronic glomerulonephritis(CGN). The type of CIC antibodies were checked again employing precipitation tests using the polyethylene glycol(PEG) technique(Abe's method). The major results are summarized as follows: 1) In $A G N$, high levels of CIC were detected especially within 4 weeks after the onset of the disease. CIC including $\operatorname{IgA}$, as well as, $\operatorname{IgG}$ and $\operatorname{IgM}$ were of ten detected using the PEG technique, but the level of CIC including IgA were higher than the others. i) The levels of CIC in poststreptococcal infec$t$ ion, wi thout renal involvement, were intermidiate-level between $A G N$ and healthy children. 3) In nephrotic syndrome, except in one case with positive HBs antigen, CIC were not cietected even in acute phase. 4) In, CGN, CIC were detected in high levels, and there was a correlation, the pattern of glomerular localization of immune complexes and CIC. The observations using Raji cell method and PEG technique may be a useful method to monitor activities of disease in patient with immunologically mediated renal diseases. 